\title{
Comparative Fire Behavior of Composite Girders under Flexural and Shear Loading
}

\author{
Naser M.Z. ${ }^{1}$, Kodur V.K.R. ${ }^{2 *}$ \\ Department of Civil and Environmental Engineering, Michigan State University, East Lansing, \\ MI, USA \\ nasermoh@msu.edu \\ kodur@egr.msu.edu
}

\begin{abstract}
This paper presents results from an experimental study on the fire behavior of composite steel girders subjected to high shear loading. Four steel-concrete composite girders, comprising of steel girders and concrete slab, were tested under simultaneous structural loading and fire exposure. The first composite girder was subjected to typical flexural loading and fire conditions, while the other three girders were subjected to high shear loading and exposed to fire conditions. The main test variables are level of composite action, type and magnitude of loading. All tested girders failed in less than one hour of fire exposure, however, their failure mode varied significantly. For instance, composite girder subjected to flexural loading failed through flexural yielding of steel girder with large rotation at end supports, while girders subjected to high shear loading failed with no signs of large deflections or rotations at end supports.
\end{abstract}

Keywords: Steel girders, fire resistance tests, shear, local buckling, composite action

\footnotetext{
${ }^{1}$ Ph.D. Candidate, Civil and Environmental Engineering, Michigan State University

$2^{2}$ Professor, Civil and Environmental Engineering, Michigan State University
} 


\subsection{INTRODUCTION}

Structural steel members, when exposed to fire, experience loss of sectional capacity and stiffness due to temperature-induced degradation in strength and modulus properties of constituent materials. In addition, these members become vulnerable to different failure modes, i.e. runaway (large) deflections, lateral torsional buckling (LTB), out-of-plane buckling (OPB) and web local buckling (WLB). A review of relevant research indicates that majority of previous experimental, analytical and numerical studies focused on flexural response of steel girders at ambient and fire conditions [1-5].

For instance, Zhao and Kruppa conducted fire tests to study the flexural behavior of fire exposed continuous composite steel beams [4]. The authors reported that such composite beams experienced signs of local buckling at the interior support. However, no further recommendations were discussed, possibly because tested beams were subjected to dominant flexural loading and thus the effect of shear and fire-induced instability could not be isolated.

Aziz et al. [5] conducted fire resistance experiments on three different composite steel girders subjected to a design fire exposure and structural loading. The objective of these experiments was to study the flexural capacity of one hot-rolled steel girder and two built-up (plate girders) subjected to fire. Test variables included: load level, web slenderness, and spacing of stiffeners. Results from these fire tests indicated that typical steel girders can experience failure under standard fire conditions in about 30-35 $\mathrm{min}$. The time to failure and mode of failure in fire exposed steel girders is highly influenced by web slenderness, spacing of stiffeners, and type of fire exposure. Steel girders fail through flexural yielding when web slenderness is around 
50; however failure mode changes to web shear buckling when web slenderness in built-up plate girders exceed 100.

Other studies in the literature have pointed out that steel girders are highly susceptible to web shear buckling failure mode under room and fire conditions [6-19]. Although web shear buckling and post-buckling phenomenon in plate girders has been extensively studied at ambient conditions (such as those reported in tests conducted by Wagner [9], White and Barker [10], Yoo and Lee [11], Basler [12, 13, 14] and Porter et al. [15]), only few experimental studies have investigated response of built-up plate girders and hot-rolled steel girders subjected to dominant shear force and fire exposure $[18,19]$.

For instance, Tan and Qian [18] conducted an experimental investigation on twelve simply-supported built-up plate girders subjected to predominant shear loading at elevated temperature. The tested girders were subjected to a steady state heating regime of 400,550 , and $670^{\circ} \mathrm{C}$ and with different beam restraint stiffnesses. Results from these tests inferred that the ultimate shear capacity in plate girders significantly degrade at elevated temperatures. Vimonsatit et al. [19] also tested a number of small-scale steel beams to evaluate shear effects on fire behavior of steel beams. Theses beams were grouped into five series, three of which were built-up sections, while the rest were hot-rolled beam sections. The test specimens were loaded predominantly in shear loading under steady-state temperature conditions at $400^{\circ} \mathrm{C}, 550^{\circ} \mathrm{C}$, and $700^{\circ} \mathrm{C}$. Results from these tests indicated that shear capacity of steel beam/girder decreases with rise in temperature and hence the authors concluded that shear limit state need to be considered in evaluating failure of steel beams/girders under fire conditions. 
Despite experimental evidence, current fire design provisions for steel girders disregards effect of shear and only accounts for flexural limit state in evaluating failure. This approach of deriving failure in fire-exposed steel girders based on flexural limit state only is valid for most loading scenarios, but may not be representative in certain situations where shear forces are dominant or shear capacity degrades at a rapid pace with fire exposure time. In order to achieve optimum and realistic fire response evaluation, different failure modes are to be accounted for in evaluating fire resistance of steel girders under fire conditions.

One of these failure modes is buckling of thin plates due to instability of the section. As part of stability based design specifications, steel girders are classified as compact, non-compact or slender depending on slenderness of the flange and web plates. This classification defines the stability state of a steel girder to better account for buckling failure mode and arrive at an optimal design of steel girders at room temperature [20, 21]. For instance, a compact section does not exhibit any local buckling and can attain full sectional plastic capacity, thus eliminating any localized failure. A non-compact or slender section exhibit either plastic or elastic buckling behavior, respectively, and fail pre-maturely through a localized failure in web or flanges, before attaining full plastic capacity.

The classification of steel girders based on sectional stability is quantified by comparing sectional slenderness of a steel section against a pre-defined slenderness limit $(\lambda)$. Sectional slenderness represents the geometric feature of web and flange plates in steel section and is computed as $D / t_{w}$ for the web and $b_{f} / 2 t_{f}$ for the flange, where $D$ is the depth of web, $t_{w}$ is the thickness of the web, $b_{f}$ is flange width and $t_{f}$ is flange thickness. Thus, sectional slenderness is a 
unique (and fixed) value for an individual plate and is independent of the loading conditions, material type or environmental (fire) exposure.

On the other hand, slenderness limit is a numerical value derived based on specific material properties and is a function of $\left(\sqrt{\frac{E}{f_{y}}}\right)$, where $E$ and $f_{y}$ are defined as modulus of elasticity and yield strength of steel. Since material properties degrade with rise in temperature under fire exposure, the value of slenderness limit will also change following temperature-induced degradation of modulus of elasticity and yield strength. Hence, at a certain point in a fire condition (temperature), the temperature-independent value of sectional slenderness can exceed that of the temperature-dependent slenderness limits and cause the web or flange (or both) to buckle. Since the web is generally much more slender than flanges, local buckling in web often initiates before flange local buckling [6-8]. Thus, steel girders are expected to undergo significant degradation in sectional capacity (especially shear capacity) due to degradation of strength properties and onset of temperature-induced web local buckling.

Shear forces can be dominant in girders under certain loading configurations such as concentrated (point) loads acting on a girder, as in the case of transfer girders. The most common example of high shear force situation is when concentrated loads are present close to support regions of girders (especially in girders connected to offset columns in high-rise buildings or large halls/openings) [22]. Another case where shear forces can be significant is in short span beams and beams with reduced cross-sectional area (i.e., coped beams) $[1,14]$. Further, deep beams and plate girders, a common feature in transfer girders or bridges, can have much lower 
reserve shear capacity even at ambient conditions, and in such girders shear effects can govern failure under fire conditions.

It is clear that there is lack of data and understanding on the behavior of steel girders subjected to combined effect of high shear forces and fire exposure. To bridge this knowledge gap, this paper presents results from experimental studies on the response of standard hot-rolled composite steel girders subjected to combined effects of high shear loading and fire exposure.

\subsection{FIRE RESISTANCE TESTS}

To study the effect of high shear loading on the response of composite steel girders subjected to fire conditions, an experimental program consisting of fire resistance tests on four composite steel girders was carried out. The steel girders were tested to failure by subjecting them to combined effects of structural loading and fire exposure.

\subsection{Test specimens}

The composite steel girders prepared for fire tests, comprised of a steel girder supporting a reinforced concrete slab. The four steel girders, designated as CB1, CB2, CB3 and CB4, were designed according to AISC specifications [21]. The steel girders made of W24x62 section (standard hot rolled section) have flange width, flange thickness, web depth and web thickness of 179, 15, 610 and $11 \mathrm{~mm}$, respectively as shown in Fig. 1. The steel sections were fabricated using A572 Grade 345 steel. The concrete slab, cast along the full length of the steel girder, has a depth and width of 140 and $815 \mathrm{~mm}$, respectively and was made of concrete of compressive strength of $45 \mathrm{MPa}$. 
The composite steel girders were fabricated at the same time, similar design and material batches was used in all girders (as that in CB1) for consistency. Hence, all girders CB2, CB3 and CB4 were designed and fabricated with one $9.5 \mathrm{~mm}$ thick stiffener at the supports and one 12.7 mm thick stiffener at the mid-span of the girder (to provide some level of lateral support to the girder). It should be noted that in order for vertical stiffeners to contribute to the shear capacity of the girder, several conditions need to be met. Since,

1. $\mathrm{h} / \mathrm{t}_{\mathrm{w}}>1.1 \sqrt{\mathrm{k}_{v} \mathrm{E} / \mathrm{fy}}$, for all tested girders; $\left[\mathrm{h} / \mathrm{t}_{\mathrm{w}}=55.1<1.1 \sqrt{\mathrm{k}_{v} \mathrm{E} / \mathrm{fy}}=59.23\right]$, and also

2. $1 \leq \mathrm{a} / \mathrm{D} \leq 3$, for all tested girders $[\mathrm{a} / \mathrm{D}=1829 / 573=3.19>3.0]$

Stiffeners provided in tested girders CB2, CB3 and CB4 will not contribute to shear capacity of the girders.

The main test variables in these tests are loading type and level of composite action. Composite girder CB1, which represents benchmark specimen, was subjected to flexural loading, while the other composite girders CB2, CB3 and CB4 were subjected to high shear loading. In addition, composite girders $\mathrm{CB} 1$ and $\mathrm{CB} 2$ were designed to ensure full composite action between the steel girder and the concrete slab, composite girders CB3 and CB4 had two rows of $19 \mathrm{~mm}$ diameter shear studs placed at $230 \mathrm{~mm}$ to achieve partial (50\%) composite action between the steel girder and the concrete slab (see Table 1). The different shear stud arrangements in these girders is shown in Fig. 1a, b and c. Finally, the concrete slab is reinforced with two layers of steel reinforcement of No. 4 rebars (at the top and bottom) as shown in Fig. 1d. 


\subsection{Test Equipment}

The fire resistance tests on composite steel girders were carried out at the structural fire testing facility at Michigan State University. This fire test furnace has been specially designed to produce varying conditions of heat scenarios (temperature-time curves) and structural loading, similar to that of a composite girder might get exposed to during a fire incident.

The furnace is made of a steel framework supported by four steel columns, with the furnace chamber inside the framework. This chamber is $2.44 \mathrm{~m}$ wide, $3.05 \mathrm{~m}$ long, and $1.78 \mathrm{~m}$ high and can produce a maximum heat energy of $2.5 \mathrm{MW}$ using six gas burners located within the furnace. Inside the furnace, six type-K Chromel-alumel thermocouples are mounted on the walls of the furnace to monitor progression of temperature. During the course of fire test, the gas supply is manually adjusted such that the furnace temperatures follow a pre-determined fire curve (standard or design (realistic)). This furnace is also designed with two small view ports provided on either side of furnace walls to facilitate visual observations of fire exposed girders.

The fire test facility is primarily designed to test simply-supported horizontal members (i.e., beams and slab) as well as vertical members (columns). Vertical loading can be applied on columns, beams or slabs using one, two or five-point loading set-up system. In order to simulate high shear forces on composite girders during fire exposure, a new loading set-up was specially developed for the current test program. The new loading set-up required addition of an intermediate support to be placed at the mid-span of a composite girder, such that high shear loading can be applied on the composite girder using two hydraulic actuators placed on the sides of the intermediate support. This modification will facilitate simply supported girders to be tested as continuous girders. The needed internal support was designed to be in the form of a reinforced 
concrete column as shown in Fig. 2. This column is of a square cross section (204x204 mm) and is casted with a special concrete mix, made of high strength concrete with polypropylene fibers. During fire tests, this concrete column is insulated with $50 \mathrm{~mm}$ thick insulation to limit temperature rise in concrete column and avoid possible elongation of column.

\subsection{Instrumentation}

The four test girders were instrumented with thermocouples, strain gauges, and displacement transducers to monitor thermal and mechanical response during a fire test. Steel temperatures were measured using $0.91 \mathrm{~mm}$ thick Type-K Chromel-alumel thermocouples installed on the lower and upper flanges, as well as on four vertical locations along the height of the web of each girder at quarter and mid-span locations. Additional thermocouples were also attached on shear studs, at mid-depth and surface of concrete slab at quarter and mid-span locations. Vertically and horizontally oriented linear variable displacement transducers (LVDT) were attached at distinct locations on the girders in order to measure axial, out-of-plane web displacement, and vertical deflections. To measure out-of-plane displacement of the web, a wellinsulated stiff threaded steel rod was attached to the center of the web panel and extended horizontally parallel to the concrete slab. The steel rod extends vertically to pass through a special opening in the furnace lid. The vertical deflection was measured through two LVDTs that were attached to the top surface of the concrete slab beneath the loading actuator. The steel frame that carries the LVDT was installed on top surface of the concrete slab (outside the furnace zone).

\subsection{Test conditions and procedure}

Each composite girder was placed inside the furnace as shown in Fig. 2. It should be 
noted that the furnace is designed for testing beams and girders with a maximum depth of 406 $\mathrm{mm}$, however, the test specimens have an overall depth of $750 \mathrm{~mm}$, and hence a new lid on the furnace was specially designed for these tests. The newly designed lid is made of an independent reinforced concrete slab to accommodate the deep steel girders and allow three sides of girders and slab to be exposed to fire during the test.

Prior to fire tests, a predefined load was applied vertically using hydraulic actuators and this load was kept constant throughout the fire test. This predefined load was of about 33-40\% of flexural and shear capacity of the tested girders and was limited by the capacity of the different hydraulic actuator systems used. For instance, in the first test, composite girder CB1 was subject to a single point load, equivalent to $40 \%$ of its room temperature flexural capacity and to $27 \%$ of its shear capacity. However, composite girders CB2, CB3 and CB4 were subjected to two point loads, placed at $430 \mathrm{~mm}$ from mid-span of the girder. These girders were tested utilizing a different set of actuators (having smaller capacity than the one used in testing of girder CB1). This is to simulate high shear forces, and full capacity of these smaller actuators was utilized. The applied loading on testing composite girders CB2, CB3 and CB4 was equivalent to 5\% of flexural capacity and $33 \%$ of shear capacity of these girders. In all four fire tests, a fire exposure following the ASTM E119 testing procedure was simulated and the tests were terminated when the girders can no longer carry the applied load.

\subsection{Material properties}

To evaluate mechanical properties of steel and concrete used in fabrication of composite steel girders, strength tests were carried out on steel coupons and concrete cylinders. For evaluating mechanical properties of steel, three coupons were cut from steel girders supplied by 
a local fabrication company. Similarly, for evaluating concrete strength, concrete cylinders were cast from concrete batch mix during fabrication of concrete slab. The average tensile strength of steel coupons is $480 \mathrm{MPa}$ and the average compressive strength of concrete used in slab is 40.6 , respectively.

\subsection{EXPERIMENTAL RESULTS}

Data generated from the above fire tests is utilized to trace the response of fire-exposed composite steel girders. Relative thermal and structural response, as well as failure modes, are compared to evaluate the effect of loading and level of composite action on the fire response of composite steel girders under high shear loading.

\subsection{Thermal response}

In all four fire tests, composite steel girders CB1, CB2, CB3 and CB4 were exposed to a typical ASTM E119 fire exposure. For evaluating thermal response of girders, cross-sectional temperatures were measured at different points of web, flanges, shear studs, and concrete slab at two traverse sections. Since these girders have similar geometric characteristics (same steel section and concrete slab dimensions), made of same material batches and were subjected to same type of fire exposure (ASTM E119), all tested girders experienced similar thermal response. Typical temperatures at selected points on girder CB2 and CB3 are plotted as a function of fire exposure time in Fig. 3.

In general, temperatures at different points on steel girder increase at a much faster pace than that in concrete slab or shear studs. Within the steel girder, web temperatures in these girders increase at a higher rate than that in top and bottom flanges (as shown in Fig. 3). This can 
be attributed to the fact that web is more slender (much deeper and has smaller thickness) than that of the flange, hence exposed surface area of web is larger than that of flanges. Figure 3 also shows that measured temperatures in top flange of steel girders are much lower than that in bottom flange. This is due to insulating effect of the concrete slab which acts as a heat sink. It should be noted that much of the heat from the top flange of girder gets dissipated to concrete slab due to high thermal capacity of concrete.

The temperature in shear studs remains much lower than that in top flange, despite the stud being welded to top flange of the girder. This is due to the better insulating properties of surrounding concrete slab which absorbs much of the heat from studs. Finally, the temperatures at mid-width of the slab increase at a higher rate as compared to temperatures at the edge of the slab (406 mm from mid-width). This can be attributed to the fact that the concrete slab absorbs much of heat from top flange of steel girders.

\subsection{Structural response}

The structural response of composite steel girders exposed to fire conditions can be assessed by tracing vertical deflection, out-of-plane web displacement, slip at concrete steel interface and failure modes.

\subsubsection{Vertical deflection}

The flexural response of tested composite steel girders CB1, CB2, CB3 and CB4 during fire exposure time is illustrated in Fig. 4a, where progression of vertical deflection is plotted as a function of fire exposure time. It can be seen from the figure that the response of the flexurally tested girder (CB1) is significantly different than that of girders $\mathrm{CB} 2, \mathrm{CB} 3$ and $\mathrm{CB} 4$ that were 
tested under shear loading. This is due to different test set-up and loading type adopted in testing these girders and their impact on the mechanism of resisting the applied loading within the composite girders. In general, the simply-supported girder (CB1) tested under flexural loading undergoes large vertical deflection at mid-span accompanied by noticeable rotations near end supports. This response is different than that observed in fire-tested girders (CB2, CB3 and CB4) loaded with high shear forces which experienced very little vertical deflection (with no signs of rotations at support regions) since the applied loading was placed very close to the intermediate support.

The response of the first tested girder (CB1) can be grouped under three distinct stages. During the first stage (Fig. 4a), the mid-span deflection in girder CB1 increases linearly up to about 10 min when the temperatures in the bottom flange and web reaches about $300{ }^{\circ} \mathrm{C}$. The deflection at this stage of fire exposure is mainly due to significant thermal gradients that lead to high thermal stresses and curvature along the girder section. The developed curvature at this stage of fire exposure is independent of loading on the girder, since this curvature results mostly from the effect of thermal gradients developed in the girder. In the second stage of fire exposure, the mid-span deflection starts to increase (between $10 \mathrm{~min}$ and $25 \mathrm{~min}$ ) due to degradation of strength and modulus properties of the steel as the bottom flange and web temperatures exceed $400{ }^{\circ} \mathrm{C}$. In the final stage of fire exposure (after $30 \mathrm{~min}$ ), when steel temperature exceeds $600{ }^{\circ} \mathrm{C}$, the mid-span deflection increases at a rapid pace due to spread of plasticity in the bottom flange, and high temperature creep effects, leading to formation of plastic hinge at the mid-span. The girder is said to attain failure when mid-span deflection exceeds L/30 (at $40 \mathrm{~min}$ ) limit as the girder cannot sustain applied loading. 
As discussed earlier, composite steel girders $\mathrm{CB} 2, \mathrm{CB} 3$ and $\mathrm{CB} 4$ were tested as continuous girders wherein a concrete column was used as an interior support at the mid-span of these girders. Since the structural loading was applied very close to the intermediate support (to simulate high shear loading), these girders experienced very low levels of vertical deflection (measured at $430 \mathrm{~mm}$ away (under the loading actuators as shown below) from mid-span (where the concrete column was placed) during fire exposure as shown in Fig. 4b. Failure of a girder under fire conditions occurs either through (1) capacity (flexure or shear) at critical section of girder falling below bending moment or shear forces due to applied loading, (2) maximum deflection exceeding L/20, where L is unsupported length (L), or (3) deflection exceeding L/30 and in combination with rate of increase of deflection exceeding $L^{2} / 3,000 d$ [23]. In the fire testing of $\mathrm{CB} 2, \mathrm{CB} 3$ and $\mathrm{CB} 4$, the maximum vertical defection in these girders ranged between 9 and $16.5 \mathrm{~mm}$ which corresponds to 7 and $13 \%$ of that of the BS-476 standard [23] deflection limit criteria. The vertical deflection of these composite steel girders is very similar in terms of magnitude and response. This vertical deflection starts to increase at the same rate throughout the fire test but remains very small (about $10-15 \mathrm{~mm}$ ) and then stabilizes which is different than that shown in mid-span deflection in CB1. Hence, it is clear that deflection in these girders is not clear representation for determining failure. Thus, failure in these girders occurs upon attaining their sectional capacity.

\subsubsection{Out-of-plane displacement}

The response of tested composite steel girders $\mathrm{CB} 1, \mathrm{CB} 2, \mathrm{CB} 3$ and $\mathrm{CB} 4$ with fire exposure time is illustrated in Fig. 5, where progression of out-of-plane web displacement is plotted. The measured out-of-plane displacement shown in Fig 5 is at a point located at the mid- 
height of the web and $430 \mathrm{~mm}$ away from mid-span (below the point of applied loading). The time and temperature to initiation of web buckling, and the maximum out-of-plane displacement in each girder are summarized in Table 2.

As discussed earlier, girder CB1 was tested as a simply supported girder with a longer clear span, than girders CB2, CB3 and CB4 which had shorter spans (therefore girder CB1 has much more tendency to move laterally). In fire test, girder (CB1) did not move laterally or experience any web lateral displacement, as noted from observations during fire test and further confirmed through review of test data (see Fig. 5). Since girders CB2, CB3 and CB4 had shorter spans than girder CB1, they also did not experience any lateral displacement. However, out-ofplane web displacement in steel girders CB2, CB3 and CB4 varied significantly. It can be seen from Fig. 5 that out-of-plane web displacement in these three girders initiated within the first 10 min of fire exposure when average web temperature reached $150-220^{\circ} \mathrm{C}$ range, and this corresponds to start of temperature induced degradation in elastic modulus of steel.

In the case of composite girder CB2, the out-of-plane web displacement steadily increases to $5 \mathrm{~mm}$ from the start of fire test till about $22 \mathrm{~min}$ into fire exposure when average web temperature is $460^{\circ} \mathrm{C}$ then rapidly increase to $25.4 \mathrm{~mm}$ at $30 \mathrm{~min}$ of fire exposure when average web temperature is $500^{\circ} \mathrm{C}$. At this point, out-of-plane web displacement increases at a higher pace to $35.6 \mathrm{~mm}$ (which corresponds to average web temperature of $590^{\circ} \mathrm{C}$ ) till failure occurs in the girder. At this point the fire test was stopped and this girder was left to cool down to room temperature. Upon cooling, further inspection was carried out and large amount of web buckling that occurred near the mid-span region was observed as shown in Fig. 6 a. 
In the case of composite girder CB3, the out-of-plane web displacement increased at a slightly faster pace than that in girder $\mathrm{CB} 2$ and reached up to $31 \mathrm{~mm}$ (at average web temperature of $505^{\circ} \mathrm{C}$ ). Then, the web displacement readings instantly increased indicating a change of displacement direction. Such sudden change of displacement direction was believed to be caused by temperature-induced instability of the web. Comparing the slenderness of the web $(\lambda=53.5)$ with slenderness limit $\left(\lambda_{p}=51.5\right)$ at that point in time (where average web temperature was $440^{\circ} \mathrm{C}$ ), it is clear that the web slenderness exceeded the slenderness limits, evaluated as per room temperature local buckling provisions. This leads to transforming of the web from a compact to non-compact web due to initiation of inelastic web local buckling. However, this sudden change lasted for few seconds before the web re-adjusted and continue to displace in the original direction as shown in Fig. 5. This is believed to be due to redistribution of stresses/forces in the girder.

Finally, the observed out-of-plane web displacement in girder CB4 was similar to that observed in girder CB2, but the extent of displacement was of higher magnitude. The out-ofplane web displacement in girder CB4 starts to increase linearly until it reaches $20.3 \mathrm{~mm}$, then suddenly drops to $31 \mathrm{~mm}$ at about $30 \mathrm{~min}$ into fire exposure when average web temperature is $500^{\circ} \mathrm{C}$. Then, additional slight increase in out-of-plane web displacement occurs and at this point, failure occurs in the girder. At the time of failure, the maximum horizontal displacement of web in girder CB4 was $36 \mathrm{~mm}$ and corresponding web temperature was $620^{\circ} \mathrm{C}$.

\subsubsection{Slip at concrete slab-steel girder interface and cracking in concrete slab}

The contact state between the concrete slab and steel girders in terms of slip at the interface and response of concrete slab was closely examined throughout the fire tests. In these 
fire tests, there was no slip at the steel-concrete interface in composite girders CB1 and CB2, but slip occurred in composite girders CB3 and CB4. This is mainly due to the fact that girders CB1 and CB2 were designed to achieve full composite action between slab and girder by providing two rows of $19 \mathrm{~mm}$ diameter shear studs at $115 \mathrm{~mm}$ spacing (a total of 36 studs), while girders CB3 and CB4 were designed for partial composite interaction (50\% of studs of CB1 and CB2).

In the case of composite girder $\mathrm{CB} 1$, there was no slip of concrete slab during fire test. Concrete slab experienced extensive cracking/crushing and a failure of the girder occurred when the concrete slab attained its flexural capacity. On the other hand, in the case of composite steel girder CB2 tested under shear loading, concrete slab in composite steel girder did not undergo any apparent cracking and remained intact throughout fire test. In the case of composite girders CB3 and CB4, a relatively large shear crack appeared at the edge of the concrete slab after 30 min into fire exposure. This crack started from the location of the shear stud positioned at the end of the girder. Once this crack propagated through the thickness of the concrete slab and reached the surface, a large separation between the concrete slab and steel girder took place. This shear crack as well as complete interface separation between slab and girder is observed in girders CB3 and CB4 are shown in Fig. 7 (the measured maximum separation between the slab and steel girder (after fire exposure) was $20 \mathrm{~mm}$ ). It is clear from these observations that the level of composite action can affect response of fire exposed composite girders when subjected to high shear loading.

\subsubsection{Failure modes}

Visual observations were made during and at the end of fire tests to capture response and development of failure mechanism in tested composite steel girders. Vertical deflections, out-of- 
plane web displacements, crack patterns in concrete slab, slip between slab and steel girder in the fire tested composite steel girders were utilized to identify failure limit states in each girder.

After fire tests were completed, the girders were taken out of the furnace for further inspection. Post fire assessment for girder CB1 indicates that flexural behavior dominated response and failure of girder during the entire duration of fire exposure. This girder experienced significant degradation in flexural capacity and thus failed through yielding at the bottom flange, large rotations at supports with no signs of local buckling in the web. The condition and failure pattern of this girder after fire test is shown in Fig. 8a. The girder forms a "V" shape at failure due to large deflections, resulting from large rotations at the girder ends and also due to crushing of concrete at the mid-span region.

Figure 8 also shows failure and magnitude of deformation in composite steel girders CB2, CB3 and CB4. Girders CB2 and CB4 failed early into fire exposure at 55 and 50 min, respectively (with no signs of large mid-span deflection or rotation at end support regions). This is due to the fact that there was less composite interaction between the concrete slab and steel girder as CB4 had half the number of shear studs as that in girder CB2.

Post-fire assessment has also showed that a small portion of fillet weld in bearing stiffener of girder CB2 ruptured (see Fig. 6b), however welds of bearing stiffeners in CB4 remained intact post fire as can be seen in Fig. $6 \mathrm{~d}$. This assessment also revealed that bearing stiffeners might have slightly buckled in both girders. It should be noted that AISC design manual states in Chapter (J) Part 10 that bearing stiffeners are required when the web has insufficient strength for any of the limit states of web yielding, web crippling, or sidesway web buckling. However, when these limits are checked at the time girders CB2, CB3 and CB4 were 
designed, it was clear that the girders do not require any bearing stiffeners. However, one pair of bearing stiffeners was added to girders $\mathrm{CB} 2, \mathrm{CB} 3$ and $\mathrm{CB} 4$ to keep the same level of bearing capacity as in girder CB1 (to have similar conditions for comparison of performance). As per AISC provisions, the addition of the pair of bearing stiffeners should increase, to some extent, the capacity of the bearing section at the interior support.

Post fire inspection of girders revealed that cause of failure of tested girders is complex and can be due to interaction of different modes. Further experiments, together with advanced numerical modeling, are needed to better understand the behavior of bearing connection, as well as interaction of bearing stiffeners and web shear buckling under combined effect of high shear force and fire exposure.

\subsection{CONCLUSIONS}

Based on the results of the analysis presented herein, the following conclusions can be drawn:

1. Steel girders exposed to fire can experience failure under flexural, shear or local instability failure limit state or due to combination of different failure modes. The current philosophy of evaluating failure of fire-exposed girders solely based on flexural limit state may not be conservative in situations where composite girders are subjected to high shear forces.

2. Under fire exposure, temperature in web of steel girders raises more rapidly than that in flanges due to higher slenderness of web. Hence, shear capacity of steel girders degrades at a faster pace than flexural capacity and this can lead to failure under shear limit state prior to attaining flexural limit state. 
3. Steel girders designed for full composite action with concrete slab, can effectively transfer some level of stresses to slabs under fire conditions and hence achieve better fire resilience than steel girders designed for 50\% composite action.

4. Composite girders loaded with high shear forces and exposed to fire do not undergo large deflections or rotations at end supports and thus, deflection limiting criteria cannot be valid in defining failure. These girders fail due to temperature-induced web shear buckling and related degradation of shear capacity.

\section{ACKNOWLEDGMENT}

This material is based upon the work supported by the National Science Foundation under Grant number CMMI-1068621 to Michigan State University. Any opinions, findings, and conclusions or recommendations expressed in this paper are those of the authors and do not necessarily reflect the views of the sponsors.

\section{REFERENCES}

[1] Vasdravellis G, Uy B. Shear Strength and Moment-Shear Interaction in Steel-Concrete Composite Beams. J. Struct. Eng. ASCE 2014;140(11).

[2] Nie J, Xiao Y, Chen L, Experimental Studies on Shear Strength of Steel-Concrete Composite Beams. J. Struct. Eng. 2004;130: 1206-1213.

[3] Liang Q, Uy B, Bradford M, Ronagh, Strength Analysis of Steel-Concrete Composite Beams in Combined Bending and Shear. J. Struct. Eng. 2005;131:1593-1600.

[4] Zhao B, Kruppa J. Fire resistance of composite slabs with profiled steel sheet and of composite steel concrete beams Part 2: Composite beams, Centre technique industriel de la construction métallique 1993. 
[5] Aziz E, Kodur V, Glassman J, Garlock M. Behavior of steel bridge girders under fire conditions, Journal of Constructional Steel Research 2015;106: 11-22

[6] Naser M.Z., Kodur V.K.R. Factors Governing onset of Local Instabilities in Fire Exposed Steel Beams. Journal of Thin-Walled Structures 2014. In press.

[7] Kodur V.K.R., Naser M.Z. Effect of Local Instability on Capacity of Steel Beams Exposed to Fire. Journal of Constructional Steel Research 2014;111: 31-42.

[8] Kodur VKR, Naser MZ. Effect of Shear on Fire Response of Steel Beams. Journal of Constructional Steel Research 2013;97:48-58.

[9] Wagner H. Flat sheet metal girder with very thin metal web. Tech Memorandum 604-606, National Advisory Committee for Aeronautics (NACA), Hampton, Va, 1931.

[10] White DW, Barker MG. Shear resistance of transversely stiffened steel Igirders. ASCE J Struct Eng 2008;134(9):1425-36.

[11] Yoo CH, Lee SC. Mechanics of web panel postbuckling Behavior in Shear. J Struct Eng 2006;132(10):1580-9

[12] Basler K. New provisions for plate girder design. In: Proc AISC Nat Eng Conf. New York: American Institute of Steel Construction. 1961, p. 65-74.

[13] Basler K. Strength of plate girders under combined bending and shear. J Struct Div, ASCE 1961;87(2):97-181

[14] Basler K, Yen B, Mueller J, Thürlimann B. Web Buckling Tests on Welded Plate Girders. Welding Research Council Bulletin 1960;64.

[15] Porter DM, Rockey KC, Evans HR. The collapse behavior of plate girders loaded in shear. Struct Eng 1975;53(8):313-25. 
[16] Alinia M, Shakiba M, Habashi H. Shear Failure Characteristics of Steel Plate Girders. Journal of Thin-Walled Structures 2009;47: 1498-1506.

[17] Shanmugam NE, Baskar K. Steel-concrete composite plate girders subject to shear loading. ASCE J Struct Eng 2003;129(9).

[18] Tan KH, Qian ZH, Experimental behaviour of a thermally restrained plate girder loaded in shear at elevated temperature. J. Constr. Steel Res. 2007;64(5):596-606

[19] Vimonsatit V, Tan K, Qian Z. Testing of Plate Girder Web Panel Loaded in Shear at Elevated Temperature. Journal of Structural Engineering 2007;133(6):815-824.

[20] Eurocode 3. Design of steel structures, Part1-2: General rules-structural fire design, Document CEN, European Committee for Standardization, UK in, 2005.

[21] AISC. Specification for structural steel buildings 360-11. American Institute of Steel Construction Inc.; Chicago, IL 2011.

[22] Hall WJ. Shear deflection of wide flange steel beams in the plastic range. Wright Air Development Center. Urbana, IL: University of Illinois. 1954.

[23] British Standard Institution, Fire Tests on Building Materials and Structures. Part 20. Method of Determination of Fire Resistance of Elements of Constructions, BS 476, 1987. 


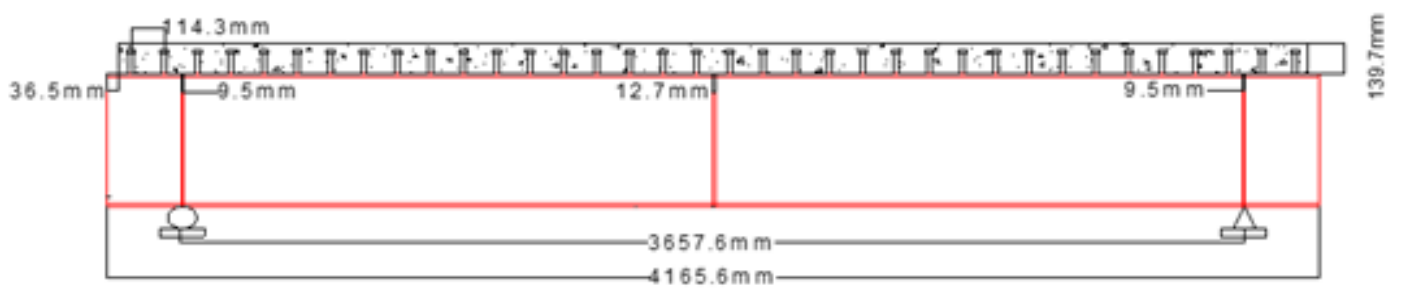

(a) Composite girders $\mathrm{CB} 1$ and $\mathrm{CB} 2$

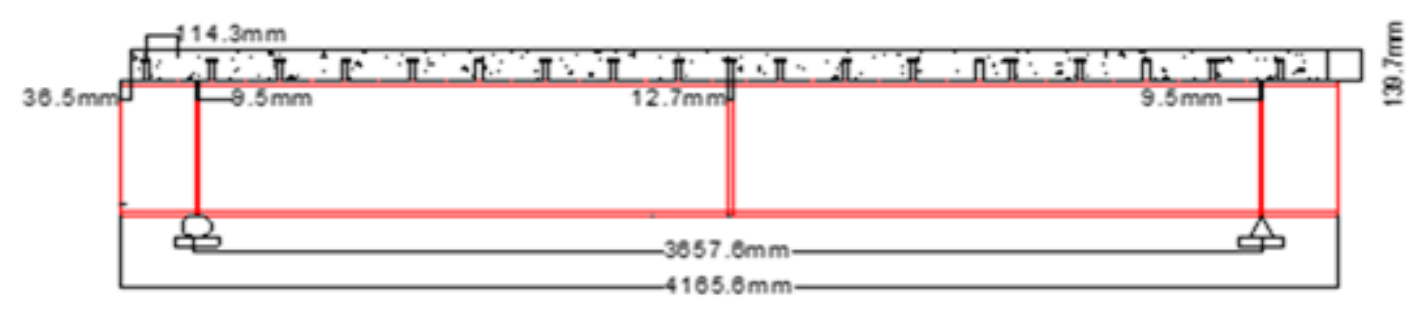

(b) Composite girders CB3 and CB4
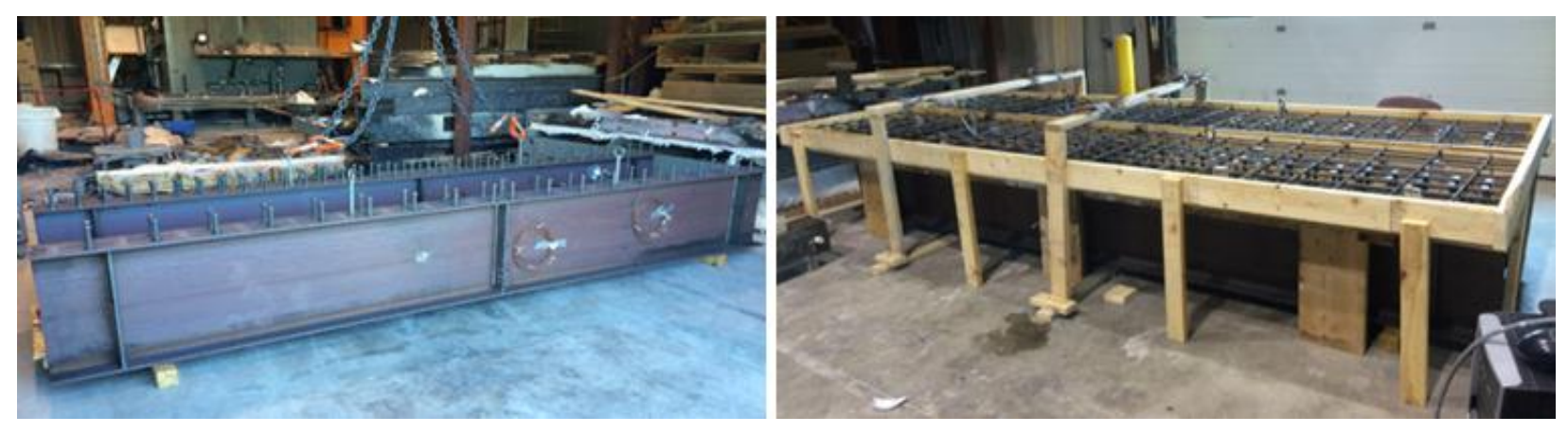

(c) Steel beams with different shear stud arrangement

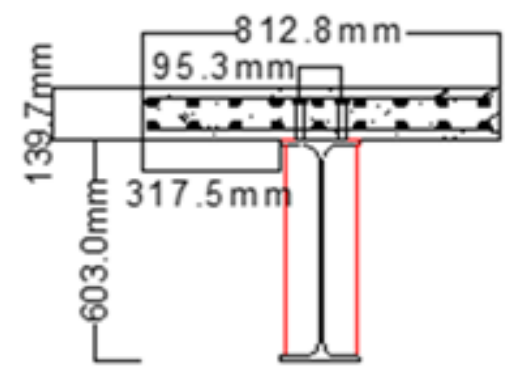

(d) Cross section of composite girders

Fig. 1 Longitudinal and traverse sections for steel girders 


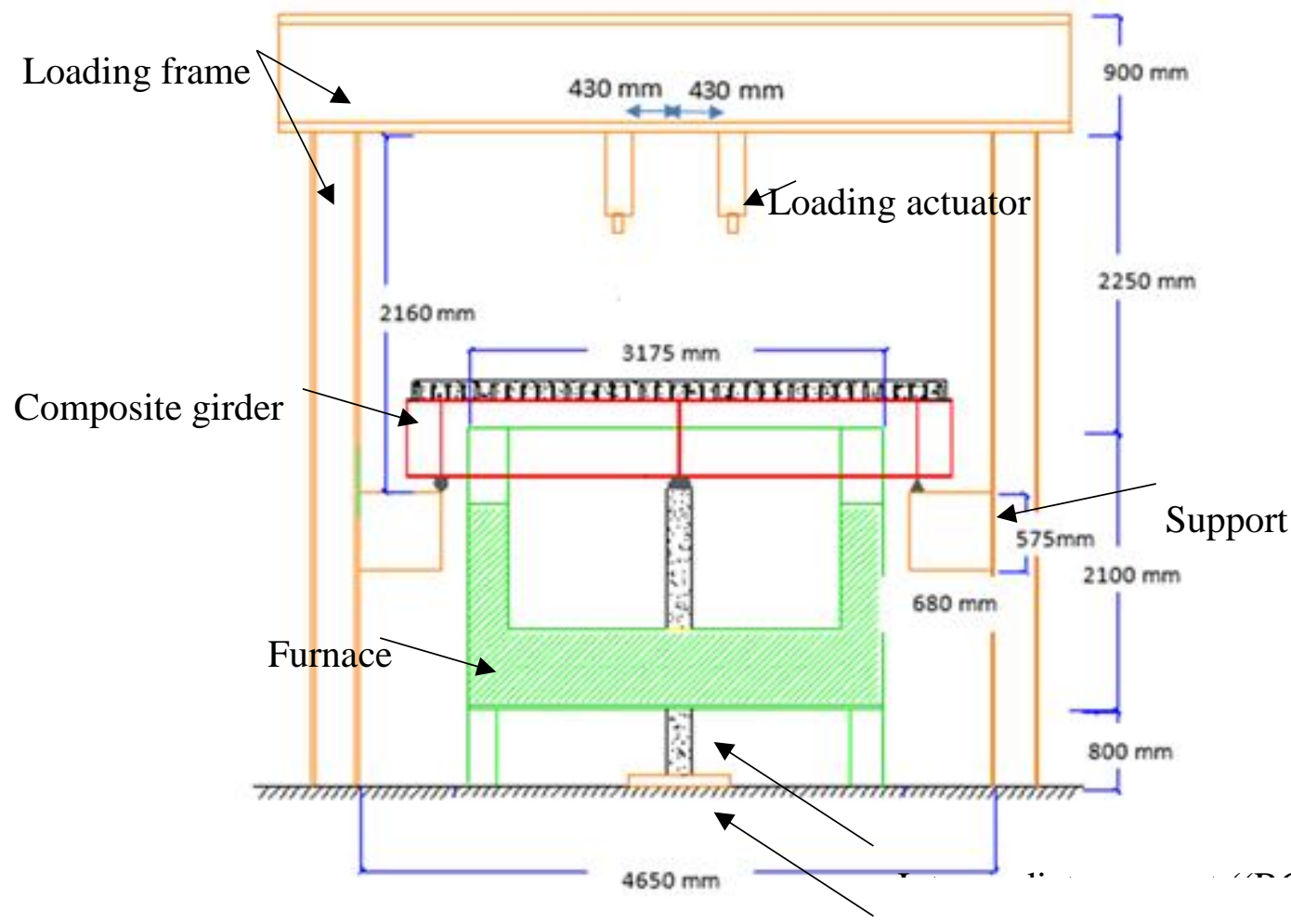

(a) Fire testing facility and loadingintarmediate support fixed-end
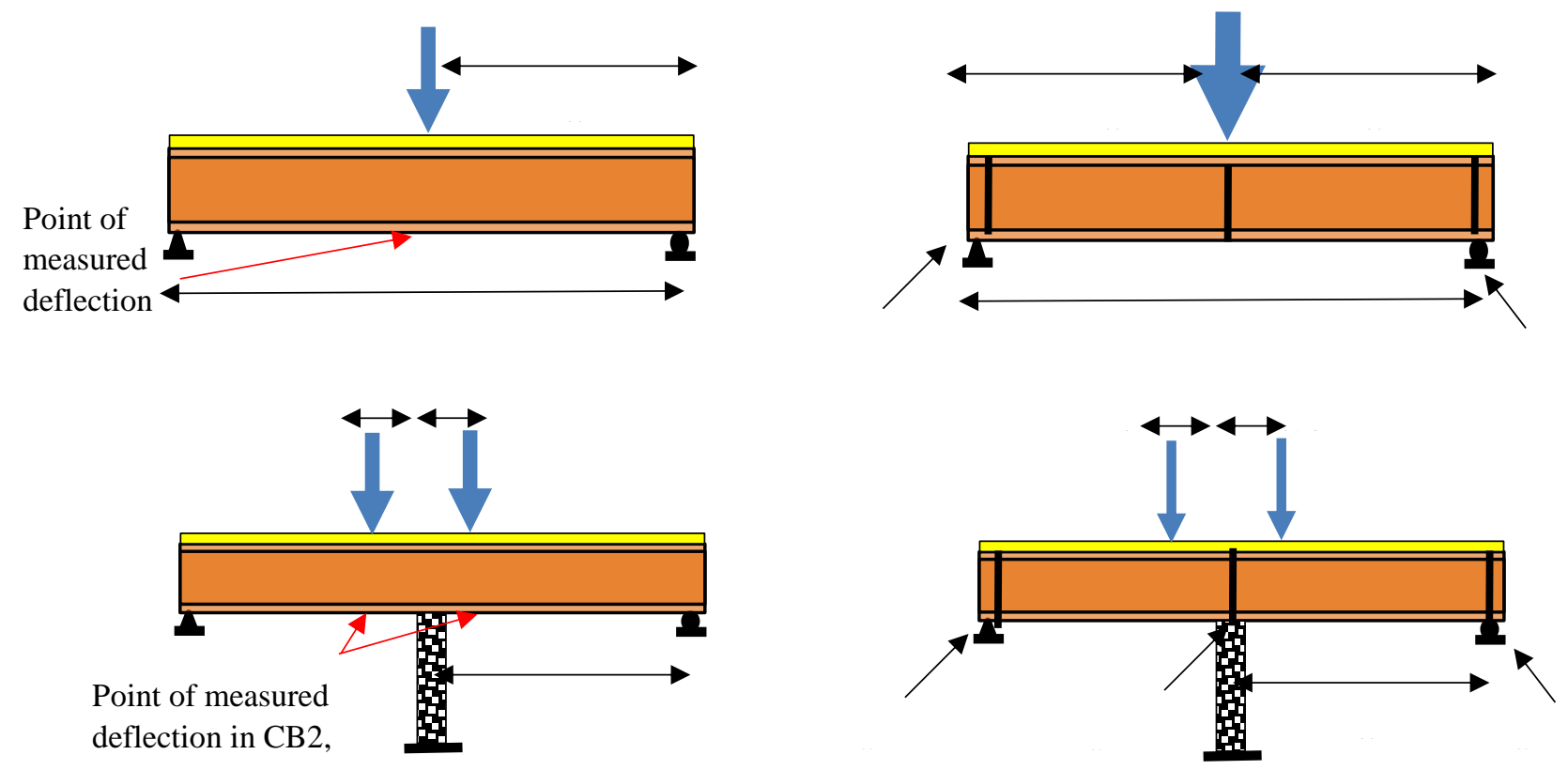
(b) Girder configuration and points at which deflections were measured in fire tests

Fig. 2 Schematic of test setup and steel-concrete beam placement in the furnace

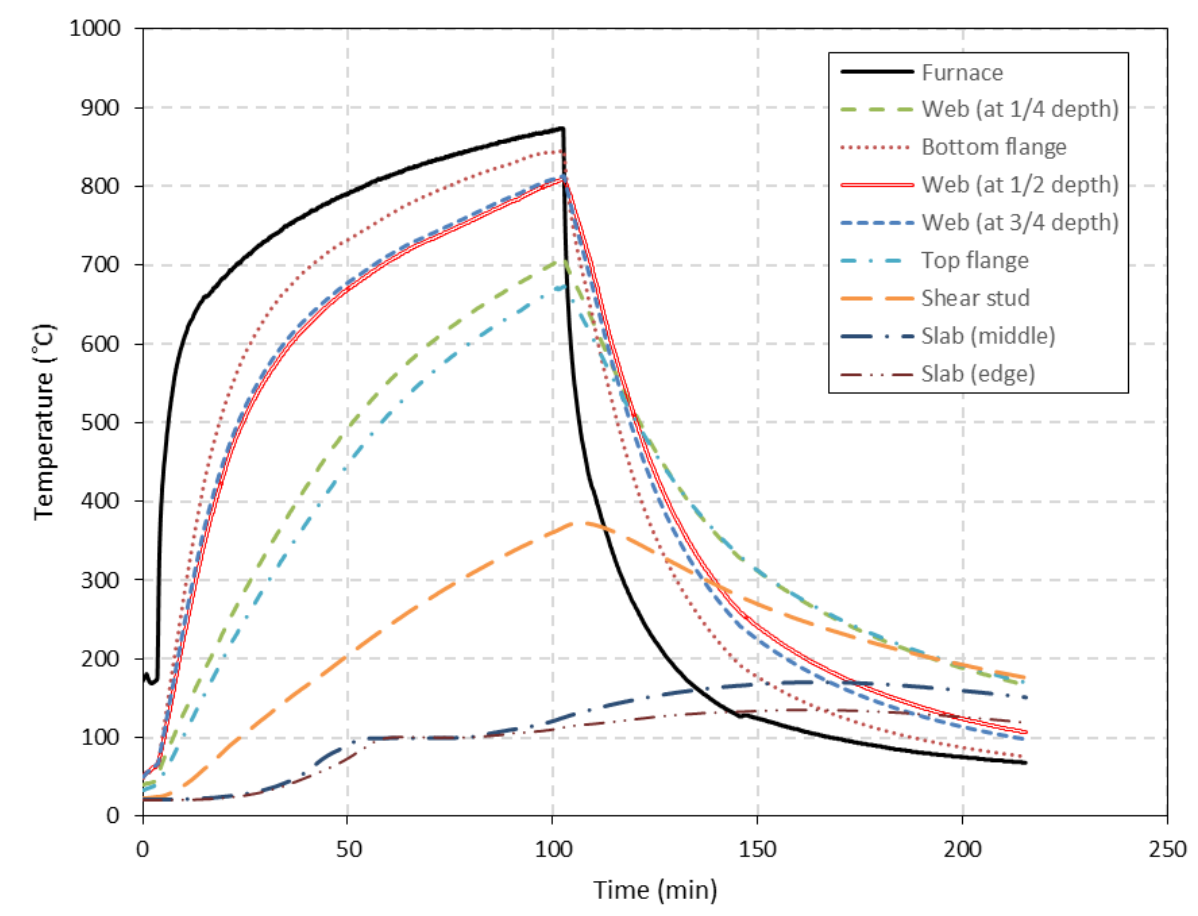

(a) CB2 


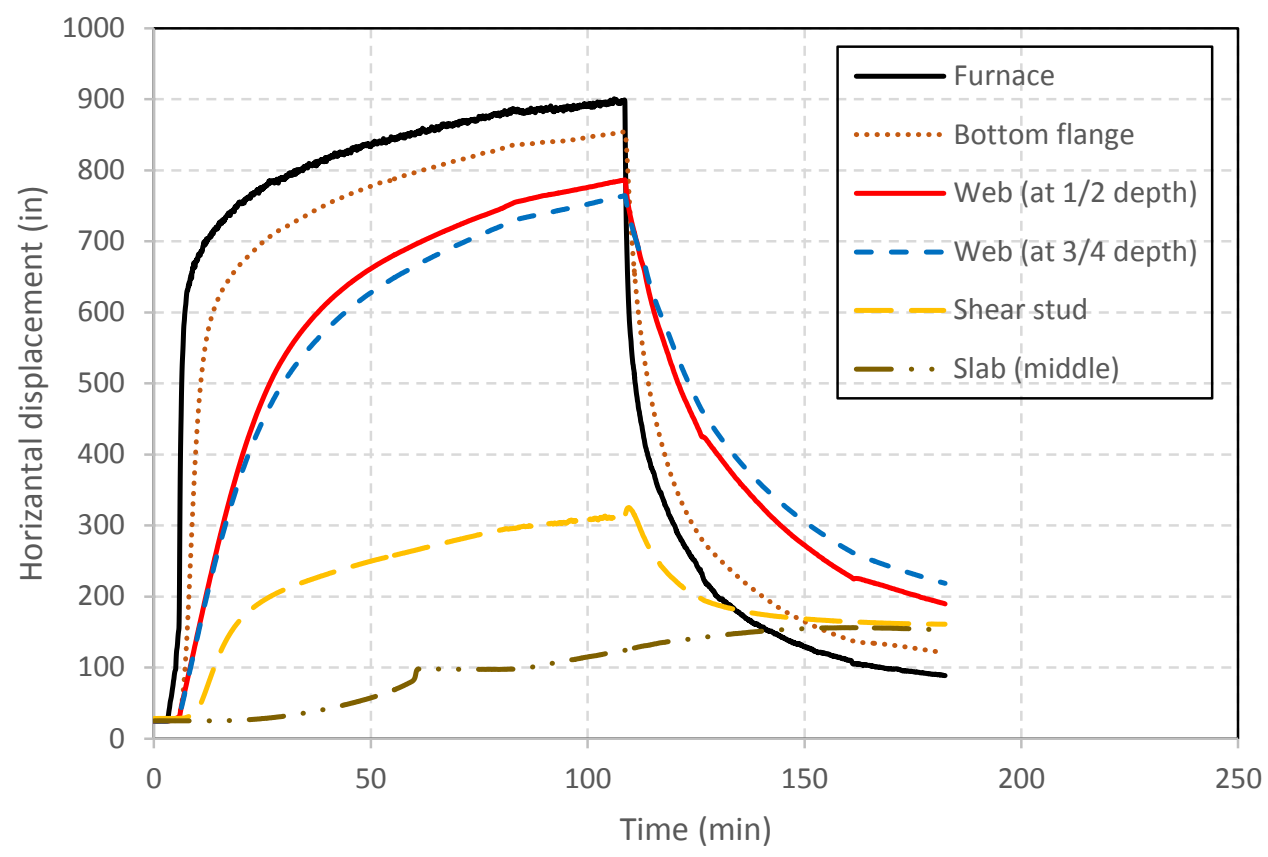

(b) CB3

Fig. 3 Measured temperature profiles in girder $\mathrm{CB} 2$ and $\mathrm{CB} 3$ as a function of fire exposure time. 


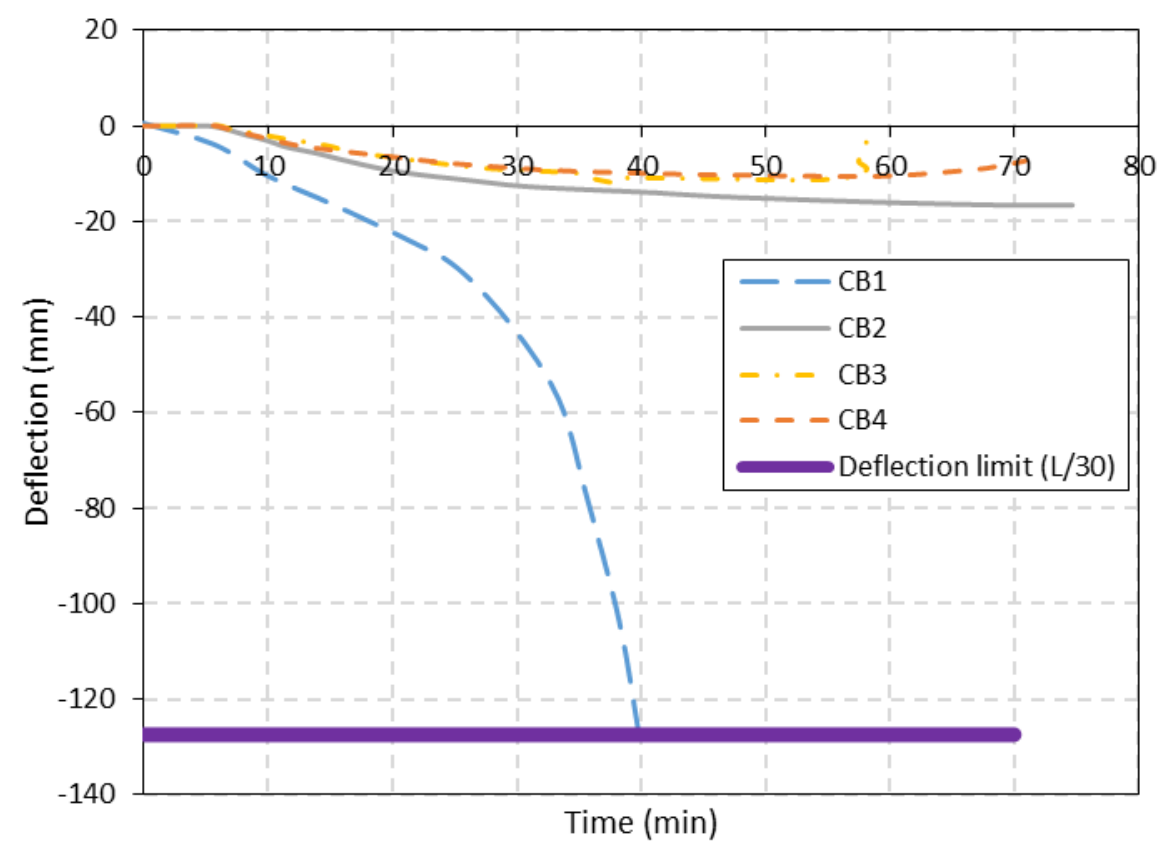

(a) Comparison of vertical displacement of CB1, CB2, CB3 and CB4

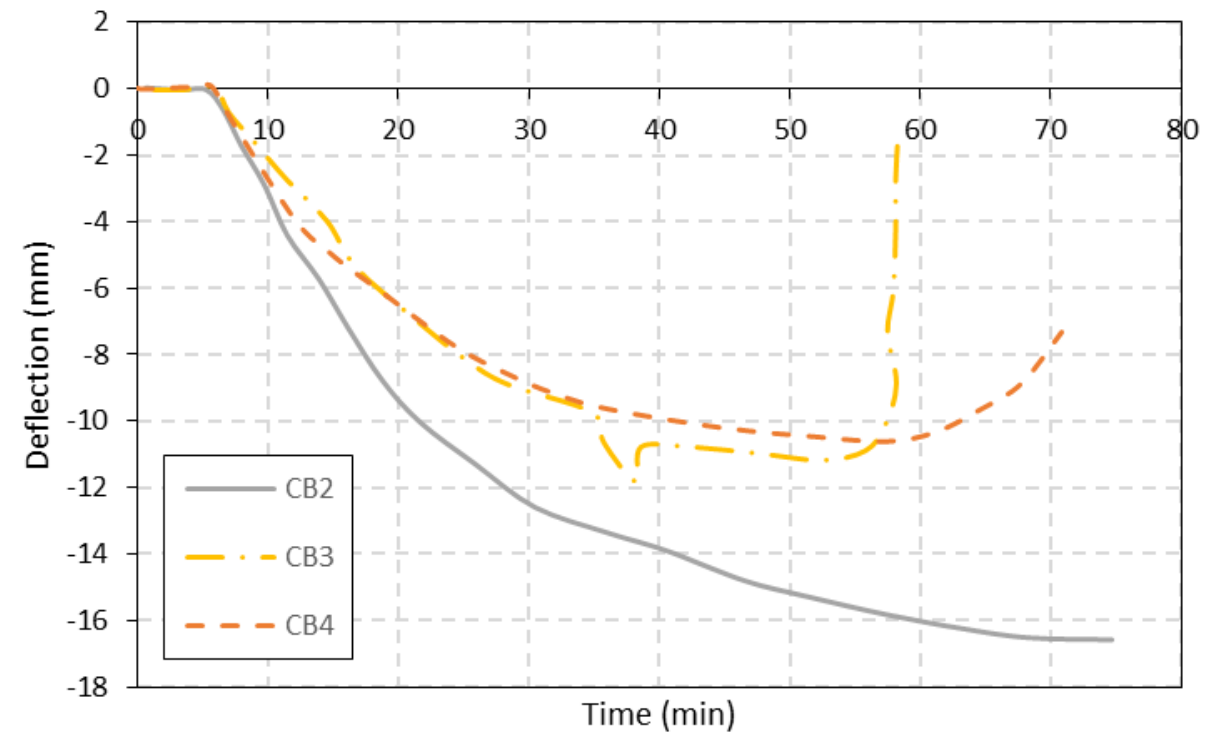

(b) Comparison of vertical displacement of CB2, CB3 and CB4

Fig. 4 Vertical displacement in steel girders as a function of fire exposure time 


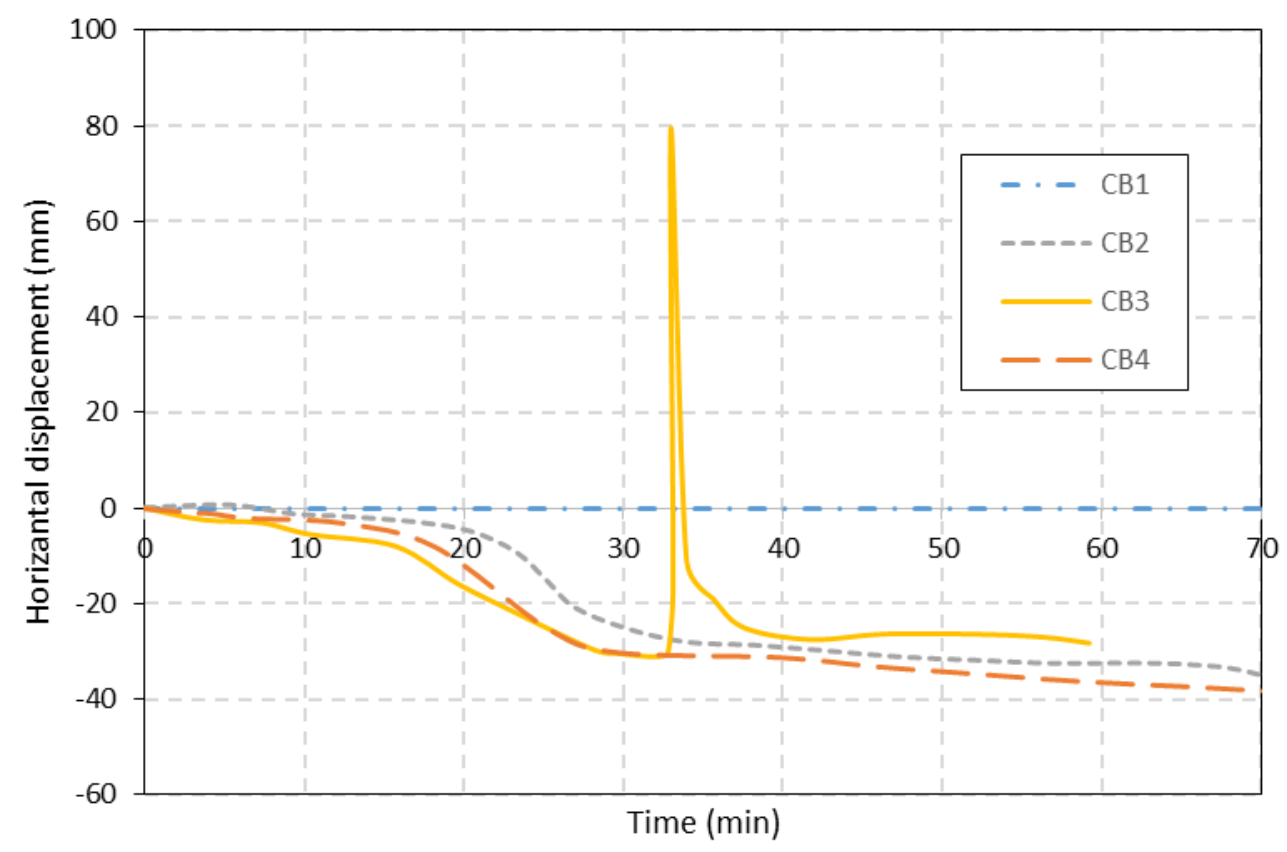

Fig. 5 Variation of web out-of-plane displacement as a function of fire exposure time in composite girders
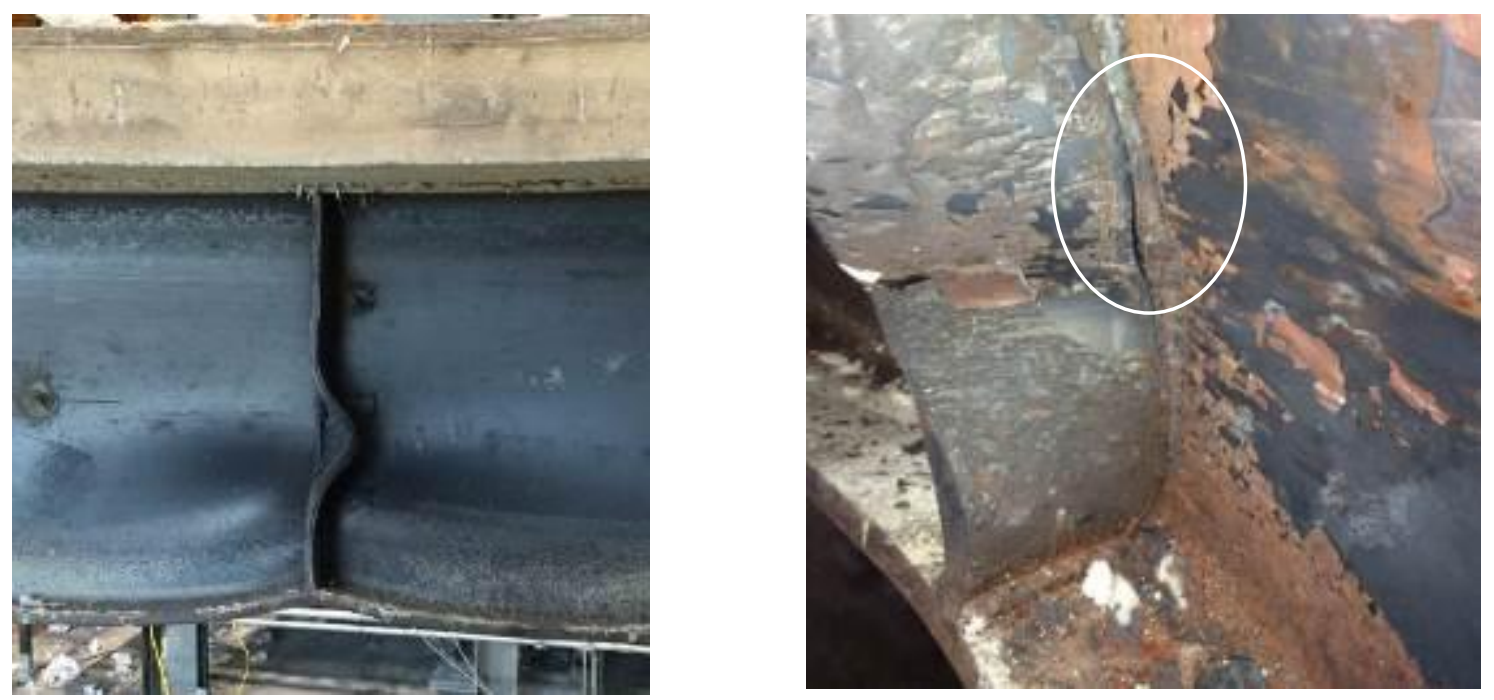
(a) State of web

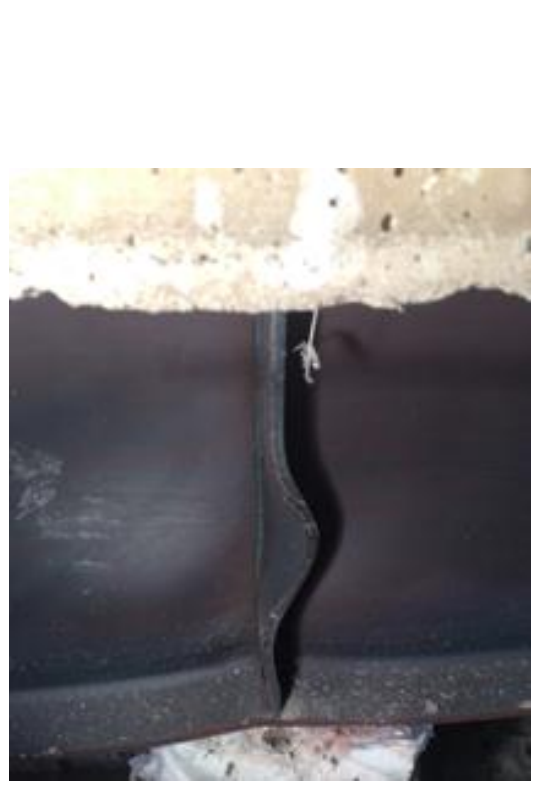

(c) State of web (b) Rupture of weld in stiffener

CB2

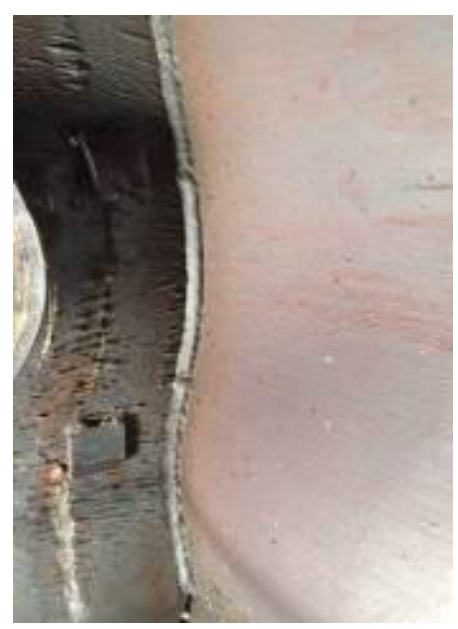

(d) State of bearing stiffener

\section{CB4}

Fig. 6 State of web and bearing stiffeners in CB2 and CB4 post fire test 

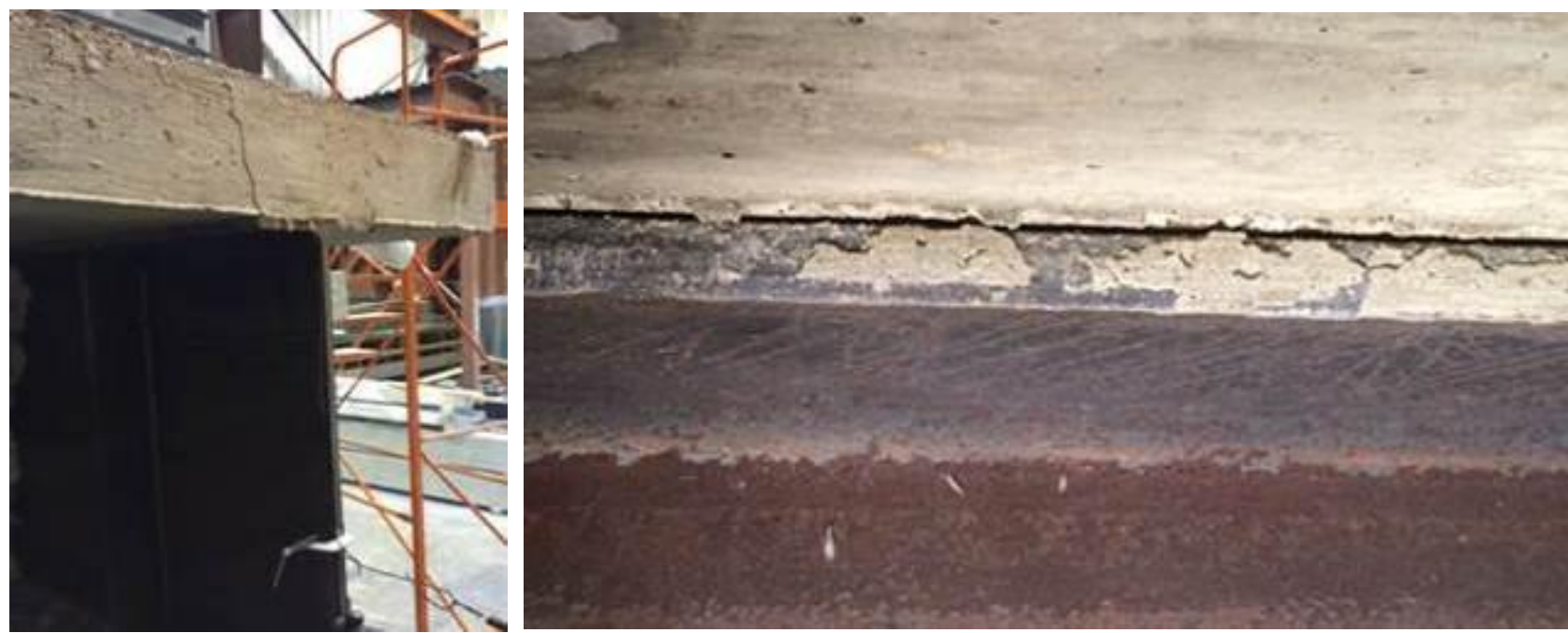

(a) Crack at end side of girder (CB3)

(b) Separation of concrete slab (CB4)

Fig. 7 Cracking and separation of concrete slab in CB3 and CB4

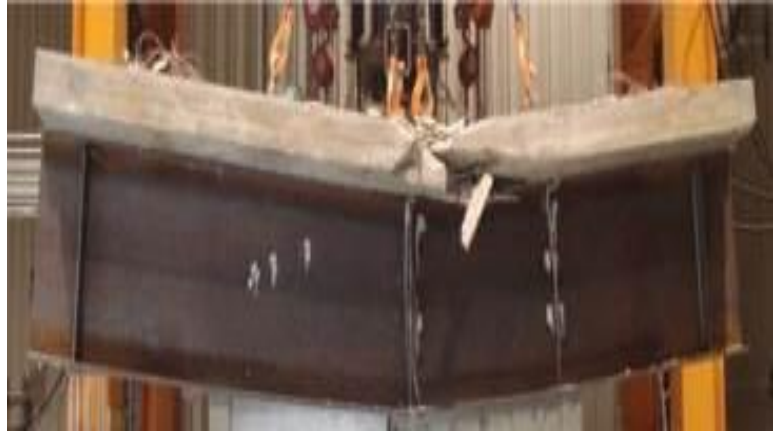

(a) Failure mode of CB1 [5]

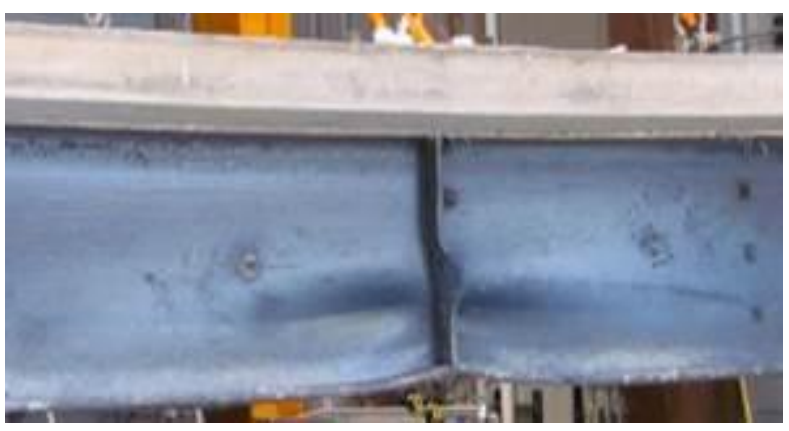

(b) Failure mode of CB2 


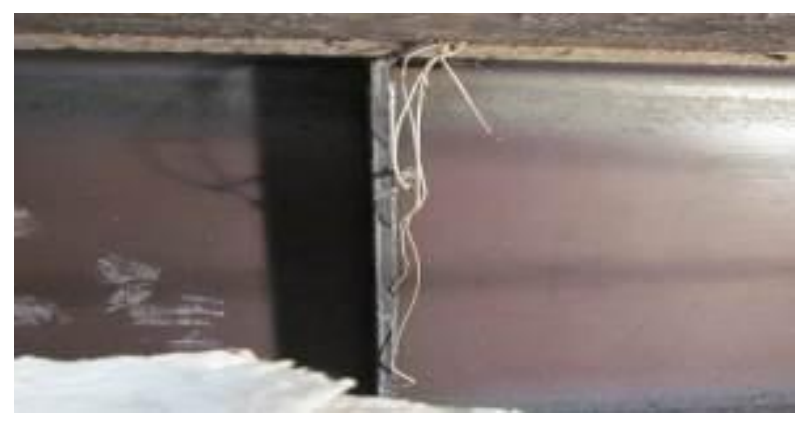

(c) Intact state of CB3 (post fire test)

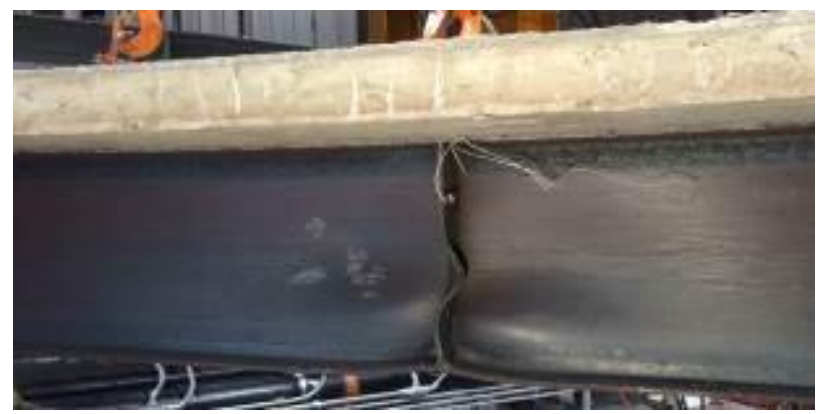

(d) Failure mode of CB4

Fig. 8 Illustration of failure pattern in steel girders CB1, CB2, CB3and CB4 after exposure to fire.

Table 1 Varied parameters in fire resistance tests

Specimen

CB1
Level of composite action

Load mechanism 


\begin{tabular}{lll}
\hline CB2 & Full composite action (100\%) & Shear \\
CB3 & Partial composite action $(50 \%)$ & Shear \\
CB4 & Partial composite action $(50 \%)$ & Shear \\
\hline
\end{tabular}

Table 2 Comparison of buckling behavior in girders CB1, CB2, CB3 and CB4

\begin{tabular}{|c|c|c|c|c|}
\hline Girder & $\begin{array}{l}\text { Time at initiation of } \\
\text { web bucking (min) }\end{array}$ & $\begin{array}{l}\text { Temp. at initiation of } \\
\text { web bucking }\left({ }^{\circ} \mathrm{C}\right)\end{array}$ & $\begin{array}{l}\text { Max. out-of-plane } \\
\text { displacement (mm) }\end{array}$ & $\begin{array}{l}\text { Temp. at max. out-of- } \\
\text { plane displacement }\left({ }^{\circ} \mathrm{C}\right)\end{array}$ \\
\hline
\end{tabular}

\begin{tabular}{lcccc}
\hline $\mathrm{CB} 1$ & - & - & - & - \\
$\mathrm{CB} 2$ & 9 & 220 & 35.6 & 590 \\
$\mathrm{CB} 3$ & 5 & 150 & 31 & 530 \\
$\mathrm{CB} 4$ & 5 & 153 & 36 & 620 \\
\hline
\end{tabular}

\section{Highlights}

- Importance of shear on fire response of composite steel girders is investigated.

- Results from fire tests and modeling on response of bridge girders is presented.

- Effect of critical factors on shear response of fire exposed girders is quantified. 
- Failure time and mode of failure in fire exposed composite girders is discussed. 